\title{
Crisis and Innovation of Liberal Democracy: Can Deliberation Be Institutionalised?*
}

\author{
CLAUS OFFE** \\ Hertie School of Governance, Berlin
}

\begin{abstract}
The paper explores the possible contributions of deliberative procedures of political will formation to solving the problems encountered by liberal democracies today. To begin with, four functions of liberal democracy are distinguished: securing international peace, guaranteeing legal as well as political peace domestically, and producing good active citizens. The following part of the argument distinguishes four structural features characteristic of democratic regimes: stateness, rule of law, political competition, and accountability of the rulers. Thirdly, a brief summary of critical accounts concerning democracy's actual failures and symptoms of malfunctioning is presented. In the final section, two families of institutional innovations that are currently being proposed as remedies for the observed deficiencies of democracy are explored: those leading to a better aggregation of given preferences of the citizens and those aimed at improving the process of preference formation itself. It is the latter, which constitutes the field of deliberative politics that is investigated at some length. Beneficial effects of deliberative procedures and essential features of deliberative structures are discussed with reference to latest developments in the theory and empirical research on deliberative democracy.

Keywords: theory of democracy, liberal democracy, deliberative politics, crisis of democracy, institutional design
\end{abstract}

Sociologický časopis/Czech Sociological Review, 2011, Vol. 47, No. 3: 447-472

Liberal democracies, and by far not just the new ones among them, are not functioning well. While there is no realistic and normatively respectable alternative to liberal democracy in sight, the widely observed decline of democratic politics, as well as state policies under democracy, provides reasons for concern. This concern is a challenge for sociologically informed political theorists to come up with designs for remedial innovations of liberal democracy. In this essay, I am going to review some institutional designs for democratic innovation. I shall proceed as follows. The first section addresses the question of the functions of liberal democracy. What are the features and expected outcomes of democracy which explain why liberal democracy is widely considered today to be the most desirable form

\footnotetext{
* The present version of this article has greatly benefited from comments by Marek Skovajsa and Pieter Vanhuysse.

** Direct all correspondence to: Claus Offe, Hertie School of Governance, Friedrichstr. 180, 10117 Berlin, Germany, e-mail: offe@hertie-school.org.
}

(C) Sociologický ústav AV ČR, v.v.i., Praha 2011 
of political rule? The second section looks at the institutional structure and the constitutive mechanisms of democratic regimes. In each of these sections four relevant items are specified and discussed. Thirdly, I shall provide a very condensed summary of critical accounts concerning democracy's actual failures and symptoms of malfunctioning. In the final section, I distinguish two families of institutional innovations that are currently being proposed as remedies for some of the observed deficiencies of democracy, with an emphasis on 'deliberative' methods of political preference formation.

\section{Four functional virtues of liberal democracy}

The question is not often asked, as its answer appears quite obvious: What is democracy good for? In fact, there are several answers, corresponding to different schools of political theory. A minimalist answer is the negative one: There is simply no normatively sustainable principle available in modern societies according to which any unequal distribution of political rights (i.e. a set of aristocratic, dynastic, imperial, ethnic, religious, or party-totalitarian privileges) and, following from that, anything but the universal accountability of rulers to the entire (adult) citizenry could any longer be defended. This is the intuition that guided Tocqueville's [1988] analysis of democracy in America (with its implications, as the author saw them, for Europe) as well as the cautious political egalitarianism of John S. Mill [1861]. Hence the equality of political rights of all citizens (as opposed to subjects) is the default position of democratic theory (a default position that, nota bene, still allows for two remaining exclusions: that of children below voting age who do 'not yet' enjoy political rights, and resident foreigners who may-or may not-be on their institutionally prescribed path to the acquisition of full citizenship ('naturalisation'). Yet beyond these two categories of outsiders (outsiders in time and outsiders in space, as it were), all 'full' members of the political community enjoy equal political rights-simply because no consensual criterion is available by which an unequal distribution of rights might be justified. Political equality is thus 'good for' forestalling any attempted relapse into a stratified system of political rights.

Yet equality of political rights and universal accountability of rulers can also be advocated on positive grounds. I wish to further distinguish three such grounds. The first (and the oldest) one is Immanuel Kant's [(1795) 2006] defence of the republican form of government (with still limited political equality and accountability, according to him) on the grounds of international peace: 'Republics' will never conduct wars against other republics-arguably one of the most robust hypotheses in the history of the social sciences. Second, a strong reason for the adoption and defence of the democratic form of government was advanced in the first wave of European democratisation after the First World War. It is, as it were, the domestic equivalent to Kant's hypothesis; it states that 'territorial' representative party democracy (together with strong elements of 'functional' 
representation through interest associations of major socio-economic categories such as employers, investors, trade unions, the agrarian sector, the civil service, etc.) will serve to institutionalise not just the condition of legal peace among individuals under the rule of law but also, thirdly, political peace among major kinds of collective interest; the latter is accomplished through the provision of institutional outlets for the organised expression and negotiation of class and other conflicts of interest. The mechanism through which democratic equality would lead to the peaceful and stable (rather than revolutionary and disruptive) processing of conflict, its accommodation, and change was thought (e.g. by Max Weber in his political writings from 1917 to 1919 and by Hermann Heller [(1933) 1983]) to reside in the voting and bargaining powers with which those inferior in socioeconomic power were to be compensated for their relative powerlessness through the constitutional provision of political resources-an arrangement that eventually would lead to a 'balance of class forces' (Otto Bauer). The socioeconomic power of investors and employers would be neutralised, at least in part, by the political power that lower classes can derive, under a democratic constitution, from their quantitative majority. If every interest were given a 'voice', nobody would have any reason to 'exit' to radical anti-systemic opposition. By virtue of its procedures, democracy is able to reconcile conflict to the extent which is necessary for the maintenance of stability, and to do so more effectively than any other form of regime.

After this hypothesis of democratic stability was brutally falsified in major parts of continental Europe in the aftermath of the economic crisis of the early 1930s, it was revived after the Second World War through an institutional arrangement and policy orientation that became known as the post-war 'Keynesian Welfare State': Political democracy, or so the basic tenet of this period can be summarised, is a stable political arrangement because (and to the extent that) it is capable of organising an ongoing distributional positive-sum game in which all sides involved-capital, labour, the public sector together with its social policies and social services-will simultaneously be able to gain, provided, that is, the material foundation of such encompassing social progress, namely continuous economic expansion, can be maintained or, if need be, effectively stimulated. This hypothesis-democracy is desirable because it generates balanced distributional progress-held remarkably true in the West throughout (roughly) the third quarter of the 20th century, i.e. the so-called 'golden' post-war period. In this period, there were no permanent losers in rich democracies. It came, however, at least in Europe, to an abrupt halt in the mid-seventies. Two books, James O'Connor [1973] and Crozier, Huntington and Watanuki [1975], noted and analysed in quite influential ways the 'crisis of democracy' or, respectively, of 'the state' that ensued when this hypothesis, too, turned out to be dubious. Reasons for scepticism were provided by the evidence of lasting high levels of unemployment, which had been building up in European democracies since the mid-1970s, declining growth rates, and the massive increase in income and other inequalities that most 
OECD economies had been experiencing since the mid-nineties. The confidence in a productivist partnership between the state and social classes that would immunise democracy against the consequences of economic crisis was soon dismissed and actively rejected by the market radical regimes of monetarist economic policies associated with the names of Reagan, Thatcher, and more generally the 'Washington consensus' and 'neoliberalism'. However, it must also be mentioned that representative democracy and universal access to political rights have in fact played a major role in preventing or reversing severe social regressions in at least some countries of the post-colonial developing world, with Indian democracy as the outstanding example. As Armatya Sen [1999] has powerfully demonstrated, there has not been a single major famine or other socio-economic disaster in a democracy, whereas such disasters were allowed to take their course in party dictatorships (such as during the 'Great Leap Forward' in Mao's China).

Throughout the Cold War, representative democracy (i.e. its defining features of the constitutionally enshrined division of powers, accountable rulers, electoral competition, and civic and political rights) has served to corroborate the claim that 'the West' is not just economically superior to state socialism owing to its far better performance in terms of economic growth and mass prosperity, but also morally superior as a regime of political freedom and equality of rights. The combined institutional arrangements of political democracy and organised capitalism performed so well (relative to the political and economic realities of Soviet-style 'really existing' socialism) that nobody in his right mind could conceivably opt for the latter. Yet after the eventual breakdown of (all European cases of) state socialism in 1989-1991, the function of liberal democracy and its 'social' market economy as a political immunizer against 'Communism' was no longer needed (which explains, for instance, the breakdown of the Democrazia Christiana in Italy in the early 1990s). Instead, the thorny problem of orchestrating democratic transitions and democratising former Soviet-ruled states appeared not just on the agenda of the transition countries, but on the Western agenda as well, including the project of enlarging the EU to the East. This new and historically unprecedented problem was not just to stabilise democratic capitalism in the West, but to initiate the building of democratic capitalism from the outside in regions where state socialism had vanished. Today, as the accomplishment of the latter task is clearly far from complete, given strong symptoms of democratic deficiency in the region of even the ten new EU member states of post-communist capitalism (to say nothing about their neighbours to the East), and as the accomplishment of the former task is outright questionable after the experience of the 2008 financial market crisis and its aftermath in both old and new member states, the blessings of liberal democracy and democratic capitalism are less evident (both to the outside observer and the internal participants) than they, arguably, were at any point since the Second World War.

Before leaving the question of what democracy is 'good for' (and here entirely skipping the question of how the political and economic realities of the 
European Union can be reconciled with democratic principles) we should at least mention a fourth theory-namely the republican theory of democratic politics and its claim that the opportunity to participate in the collective affairs of the political community will actually have a virtuous formative impact upon citizens. This impact is thought to enable him or her to be a 'good' citizen, i.e. a citizen both able (through enhanced understanding of public affairs) and willing (through the perceived moral obligation to transcend narrow and short-sighted interests) to serve the common good of the political community as a whole. As I will try to show at the end of this essay, it is this argument in support of the democratic regime form that has powerfully re-surfaced in debates on the reasons for and the future of liberal democracy.

\section{Four defining structural features of liberal democracy}

I propose a definition of liberal democracy (LD) here that consists of four basic elements: stateness, rule of law, political competition, and accountability.

(1) Stateness-We need to realise that LD is a regime form that (so far) is tied to states. Democrats may advocate supranational or even global forms of democracy, but that amounts to a project that is, for the time being, evidently far from being realised. At present only states (in their turn defined by the coincidence of a territory, a people, and an effective apparatus of political rule) can be democratic.

Democracy remains thus, for the time being, plainly parasitic on statehood. It is also the case that statehood always precedes democracy in historical time. For democracies appear to be always 'successor regimes', following upon non-democratic regime forms in a process of democratic transition, or democratisation, of a pre-democratic (military, authoritarian, theocratic, totalitarian, colonial etc.) regime ruling over the state's territory and population.

Another link between stateness and democracy is this: In order for a state to be democratic in any meaningful way, it must possess a minimum of what is now often referred to as 'state capacity' or 'governing capacity'. State capacity is the quality that allows a state, for instance, to protect its citizens from military or economic harm, to extract and allocate significant fiscal resources, defend the territory as well as its own monopoly on violence, establish and maintain an educational system, legislate and enforce regulatory laws, provide a measure of social and physical security and welfare, and manage succession crises-all this without being significantly obstructed by so-called factual powers, be it criminal gangs and Mafia organisations, separatist ethnic mobilisations, armed forces of civil war, networks of predatory corruption, external political forces on which governing elites are dependent, or hostile religious movements. In other words: In order for a state to be a democratic state, it must be capable of delivering collectively binding decisions and an extensive variety of (often fiscally costly) public goods. If it is unable to do so (and to do so continuously over time and territorial 
space!) we speak of a 'failed' or 'failing' state. The latter is defined by its deficient governing capacity relative to the kind and volume of problems problems that must be solved by the state to ensure social integration and the systemic stability of societies. More specifically, governing capacity (the opposite of 'ungovernability') is deficient if the state suffers from three all-too-familiar, as well as causally tightly interrelated, 'absences': the absence of borders (to control the outward flow of capital and the inward flow of goods and people); the absence (owing to the often giant and generally increasing levels of public debt) of fiscal resources available to fund public policies that serve any version of the public good; and the absence of jobs, which would allow the entire working-age population to participate, under acceptable terms, in the production and distribution of economic output.

If that is right, it would be a mistake to associate only impoverished third world countries and their feeble and often corrupt governments with the condition of 'state failure'. States with industrially advanced economies that are fiscally starved or in which elites subscribe to a doctrine of economic market liberalism and the radical retreat of 'bureaucracy' and regulation also can suffer from the syndrome of state failure and ungovernability. These conditions threaten to render democracy largely pointless, particularly if, as in the EU, major parts of remaining governing capacities are being transferred to supranational agencies (such as the European Central Bank, the European Court of Justice, the European Commission) which are operating beyond the reach of effective democratic accountability mechanisms. Neoliberal states are regimes whose policy agenda is so restricted that the substantive concerns of the 'people' remain largely bracketed out from it and have no access to the making of public policies, as major areas of public interest (urban development, health, education, the environment, transportation, utilities, etc.) are taken off the agenda of political authorities in the name of privatisation, deregulation, marketisation, competitiveness, and efficiency. Here, the universalism of political rights comes to stand in stark contrast to the more and more limited uses to which citizens can actually put their rights, given the restricted nature of the collective functions states are financially able, and governing elites politically willing, to perform.

The discrepancy between the political rights non-elites enjoy and constraints imposed on political elites' agendas by the factual powers of global financial markets and other supranational wielders of economic, political, and military power can cause citizens to turn away from democracy in one of two directions: they either give up the belief that political rights can be instrumentally useful for promoting their interests and improving the well-being of the political community as a whole - the familiar and today widespread attitude of distrust, apathy, political disaffection, and cynicism [Crouch 2004; Torcal and Montero 2006]; or, even worse, they may come to conclude that political rights, having become a blunted sword, must be beefed up with additional and non-representative political resources, such as outbursts of populist mobilisation and violent protest directed at 
alleged 'enemies'. As to the former alternative, it is worth keeping in mind the apparent paradox of 'participatory inequality' [Lijphart 1997]: it is precisely the less privileged strata of the population who would most benefit from the use of their political rights if state capacity were less constrained and who are most likely to drop out of participation, given their experience of and frustration over those constraints. As to the latter, the quest for additional political resources can also lead to large segments of the population resorting to non-institutional, disruptive, and more or less violently aggressive modes of political contestation which defy the official procedural rules of making collectively binding decisions.

The two conventional criteria of the strength and stability of democratic states are legitimacy and effectiveness [Lipset 1981]. By legitimacy we mean the quality of the holders of state power to have their decisions complied with (without the more than marginal use of coercion) even by those who see their interests and values damaged by those decisions. By effectiveness we mean the capacity of 'getting things done', solve problems, and implement plans and projects. A democratic state is stable and resilient (or 'consolidated') if and to the extent that its legitimacy and effectiveness are continuously enacted, demonstrated, and therefore taken for granted by all relevant actors, inside and outside of the state in question. But such 'taken-for-grantedness' is never irreversible: Democratic regimes can 'de-consolidate' and reach a point of self-subversion which may end in the suicidal subversion of democracy by (apparently) democratic means. Moreover, the two are related to each other in tight interaction: A state that fails to 'get things done' (e.g. because of widespread corruption or the deficiency of fiscal resources) will lose its legitimacy, and the loss of the latter will further undermine its capacity to govern.

(2) Rule of law-Democratic states are states with a (mostly written) constitution, which provides for (at least) two ways in which the exercise of state power is limited. One of these ways is to endow citizens with a bill of equal rights which cannot be legally infringed upon by governing authorities. These rights include personal rights (protecting the integrity of body and soul/conscience), economic rights (property and contract), political rights (of assembly, media communication, association, participation, etc.) and often also 'positive' social rights (social assistance, social insurance, regulatory intervention into markets, the state-supervised provision of services such as health and education). Democracies are 'liberal' to the extent the substantive range of possible democratic decision-making is strictly limited and governments are effectively hindered from interfering with the political and civic freedoms of citizens. For instance, the citizens' equal right to democratic participation is not itself at the disposition of those participating in the democratic process; i.e. it cannot be denied to minorities by majorities. Liberal democracies establish a precarious balance between collectively binding rules that are the outcome of democratic decision making (ordinary laws) and rules which are (at any given moment, at any rate) immune from such outcomes. The other limitation of overall state power (to which I shall return) is the division 
and mutual constraint of (legislative, executive, federal, juridical,) state powers, with one of the most inconspicuous (though highly consequential) constraints being the temporal limitation of government (meaning that the tenure of elected office is always ex ante time-limited and elections are periodic).

(3) Democracies organise political competition and institutionalise the non-violent conduct of political conflict between contending groups (parties) aspiring to government office. Winning contested elections is the procedure through which rulers gain their governing power-which means that elections generate losers (i.e. defeated parties and their supporters) who are expected to recognise the victory of the winner as legitimate-as a binding fact, if only for the time being, namely until the next election day. The identity and configuration of contending political parties is in part an artefact of the electoral system (with majoritarian electoral systems of the 'single member plurality' (SMP) type normally leading to a twoparty system), in part a reflection of social cleavages (of class, religion, regional or national identities) and their organisational representations (trade unions, faith-based organisations). Democracy is the scene of 'democratic class struggle' [Lipset 1981], as well as other kinds of struggle for political power-struggles the outcome of which has (unless the state's capacity and agenda is severely constrained, as just discussed, by fiscal and/or ideological limitations) significant implications for people's life chances and the distribution of their capabilities.

Yet not all political competition, as carried out in electoral campaigns, is of such a substantive sort. Political sociologists distinguish between three types of competitive struggle: First, the struggle over alternative ideological and programmatic positions and goals of political parties, with the core issue being the extent to which market forces vs interventionist regulatory and distributive policies as well as social rights can and should be relied upon. Second, the struggle over alternative answers to current issues, such as 'should we withdraw our troops from Afghanistan?' or 'should we diminish our dependency on nuclear energy by investing in renewable sources of energy?'. Third, the struggle between persons competing for the trust and electoral support of constituencies that they need for their access to leadership positions in government. Most comparative and historical research on the development of these three kinds of competitive contestation supports the generalisation that parties increasingly fail to offer (and voters fail to appreciate) distinctive and encompassing programmatic positions and instead appeal to increasingly 'volatile' voters by taking positions on (and claiming superior competence for the management of) specific issues such as tax, environmental, labour market, economic, or health policy. Another trend is the growing preponderance of the 'personality' of contending political elite figures, with the design of the image and public appearance of personalities becoming increasingly the professionalised business of media and communication experts.

The ongoing surveying and measuring of public opinion trends also allows professional political communication experts to design, on behalf of the par- 
ties and elites they serve, a promising synthesis of these dimensions of political competition. There is in many OECD countries a clear tendency, and not just in the presidentialist systems, to personalise political conflict by giving (arguably undue) emphasis to the third of the above dimensions of conflict, namely leadership personality. This shift of conflict may not only have to do with the 'end of ideology' and the secular approximation of social democratic forces to market-liberal views and programmatic outlooks, but equally to the media-based nature of the competitive struggle of politics. The archetypes of 'winners' and 'losers' in the drama of a 'fight' among concrete persons can appeal to the passions in ways that are hard to match by ideological stances and positions taken on controversial policy issues. Not only are persons, as compared to issues and programmes, more easily (and more economically) portrayed and represented by print and electronic media alike; the 'like/dislike' (or 'trust/distrust') code of personalised conflict is also the more easily and deeply engrained into citizens' memory, while loyalties, judgements, and preferences concerning policy issues and overarching programmatic ideas are more demanding to establish in any durable fashion. It often seems that the vehemence of personalistic political competition is the greater the smaller the actual differences between the contending parties are concerning their programs and policy platforms, as all major parties try to cater to the 'median voter' and the practice of state craft is degenerating into mere stage craft (Wolfgang Streeck). As a stylised extrapolation of the trend from programme competition to issue and finally personality competition we may envision a condition in which the electorate makes collective decisions at best on who governs while losing control over, even a cognitive grasp concerning, what governing elites (will) actually do, in substantive policy terms, with the mandate to govern granted to them by their constituency.

The personalisation/presidentialisation of politics often culminates in the 'populist' confrontation of personalities combined with moralised identity issues sometimes bordering on culture wars. This confrontation is designed to pose us, the good, honest, decent, hard-working, and deserving people, as represented by a trustworthy leader (self-styled as 'one of us'), against them, the evil, suspicious, corrupt, unproductive, and undeserving if not positively dangerous opponents. Populist politics are thus both unifying and divisive. They try to unify people on the basis of simple moral truths (which are held to be self-evident and do not require much of an effort of argument and reasoning) and do so by opposing 'all of us' to categories of people that need to be stopped from inflicting further damage on 'us'. Populists and populist parties pick either of two kinds of foes. One is the ruling political elite (the 'political class') itself, together with its bureaucrats, alleged cronies, and other beneficiaries of more taxes, more centralisation, and more regulation. This libertarian, often anti-statist variety of populism defends not just free markets, but also the autonomy of local communities and regional identities. This kind of populism is currently most clearly represented by the American 'Tea Party Movement' and its vehement opposition to big/central 
government and big spending. The other variety of populist divisiveness frames the 'otherness' that is to be opposed not in anti-elite but in anti-minority terms: the category of people that is to be opposed are foreigners and foreign powers, migrants and refugees, ethnic minorities, and people on welfare. The dynamics that are at work in either of these variants of populism often lead to the crossing of the conceptual border line between adversaries or opponents more or less respectfully competing under mutually recognised rules for political power and enemies involved in a struggle in which the confrontation is over the denial of the other side's rights and the legitimacy of its presence. It is the attempted fusion of these two kinds of 'otherness' - others at the top (the centralised taxing state) and others at the bottom (migrant minorities) - that makes up the success formula in the rhetoric and politics of populist leaders (a fusion that has gained electoral strength in Europe in countries as different as Norway and Hungary) that can eventually challenge the viability of liberal democracy as it calls into question and actively undermines the fundamental democratic principle of requisite stateness and the equality of political rights.

(4) Accountability-My last defining criterion of the institutional structure of liberal democracy is the presence of mechanisms which serve to hold ruling elites accountable for what they do, including what they fail to do. There are three kinds of such accountability enhancing institutional devices. First, in a vertical perspective and through the mechanisms of periodic general elections, party competition, and the investigative reporting of free media, citizens have the opportunity of removing governing elites and majority parties from office if they are dissatisfied with their performance and policy decisions and, nota bene, if they have reasons to expect that a respective alternative governing elite is likely to deliver more desirable outcomes. Absent such a credible alternative, accountability mechanisms in terms of policy run idle or are limited to alternative makers of basically identical policies. Second, wrongdoings of incumbent governments can be exposed as such, through horizontal accountability mechanisms, by parliaments and parliamentary committees as well as by constitutional (or 'supreme' or 'high') courts. Third, much of correction of (putative) failures, errors, and malfunctioning of government policies takes place through the ongoing and inconspicuous influence of organised interests and their veto power (which consists in an often ambiguous mix of threats, warnings, and conditional promises). The use of such power is typically focused upon alleged negative impacts certain government policies (such as fiscal reforms) are claimed to have upon macroeconomic key variables such as growth, employment, competitiveness, and fiscal and monetary stability.

Yet governing elites can also defend themselves against and escape the consequences of being held accountable for undesired results of their policies and decisions. 'Blame avoidance' is known to be a dominant tactical motivation of incumbent governments. [Rosanvallon 2008] As the opposition party often does not have more desirable policy alternatives to offer, replacing the incumbent gov- 
ernment by one that is led by the opposition is often not a promising move from the point of view of voters. In our age of 'globalisation', frustrating policy outcomes can be blamed on forces that are allegedly beyond the control of national governments-for instance, forces such as the financial market crisis. Margaret Thatcher's famous TINA argument ('there is no alternative') is often endorsed by economic orthodoxies that unfold, with a questionable claim of scientific objectivity, in all kinds of consultative bodies and in the media. Also, in an age of 'governance' (usually understood as the multi-actor and multi-level configuration of policy actors), it is hard to see who exactly is to blame for negative results and how to locate a responsible actor. Finally, governments have numerous means (among them the subtle forms of control over the media, government-sponsored information campaigns, the tactical timing of decisions, clientelism, keeping failures secret or obstructing their public uncovering) to immunise themselves against accountability mechanisms.

\section{Diagnostics of democratic failure and the need for democratic innovation}

According to the diagnosis of prominent democratic theorists, we are in the midst of a second transformation of democracy [Dahl 2000; Warren 2003], with the first one being the transition from direct (agora, town hall) democracy to party-dominated representative mass democracy. There is now a recent and abundant literature on the 'crisis' of democracy [Crozier, Huntington and Watanuki 1975; Pharr and Putnam 2000; Rosanvallon 2008], even 'the end' of democracy [Guéhenno 1993], the 'end of politics', or the rise of 'post-democracy' [Crouch 2004] and the para-statist making of public policies by transnational corporations and their in-house conversion of economic into political power [Crouch 2008]. One of the context conditions that triggered these perceived challenges may have been the breakdown of state socialism. As long as state socialism existed, Western democracies could content themselves with claiming (and in my view rightly so) that they performed normatively as well as economically 'better' than their authoritarian counterparts. Yet, that counterpart having become obsolete, they now have to demonstrate (and to provide compelling argument) that they are 'good', i.e. normatively sustainable, on their own terms. What needs to be shown in a persuasive way is that the institutional structures and mechanisms of liberal democracy (as summarised above) are actually capable of delivering the functions (as discussed in the first section) for the performance of which liberal democracy is held to be the most desirable form of political rule. This demonstration is not an easy task, to put it mildly. Causal narratives on the crisis of democracy include economic globalisation and the absence of effective supranational regulatory regimes; the exhaustion of left-of-centre political ideas and the hegemony of market-liberal public philosophies, together with their anti-statist implications; and the impact of financial and economic crises and the ensuing fiscal starvation of nation states which threatens to undermine their state capacity. 
For reasons of limited space, I shall mention in a stenographical manner only some of the trends and symptoms that have led authors to speak of the 'crisis' - or creeping deconsolidation-of liberal democracy. In most liberal democracies there is a secular decline in electoral turnout [Dalton 2004]. Also, class-specific turnout rates in general elections are drifting apart, with the least well-to-do showing the lowest interest in voting in elections, and even more so in engaging in the more demanding participatory practices of joining (movements, political parties, associations) and donating (of money, expertise, time). ${ }^{1}$ This trend is accompanied by a sharp decline in citizens ${ }^{\prime}$ trust in politicians. Both in new and in old democracies, apathy, cynicism, and a sense of powerlessness are on the increase. Many of the terms that have been used to describe the situation of widespread political alienation start with a 'dis': dissatisfaction, disenchantment, disappointment, the sense of the people being disempowered by elites, depoliticisation, and disaffection [Torcal and Montero 2006]. In sharp contrast to the decline of European democracies in the inter-war period, however, such alienation has not given rise to explicitly anti-democratic movements. People remain democrats, if 'frustrated democrats' [Dalton 2004]. Similar trends have been documented concerning all kinds of associations in general (again, with a class bias) and membership in political parties in particular. It has been argued that contemporary democracies are in fact 'post-liberal' in that they are populated, at the level of the inputs of demands and preferences, by two categories of citizens: first, ordinary 'natural' citizens-individuals who vote and participate in various ways - and second, a poorly legitimated class of 'secondary citizens' which consists of associations, pressure groups, lobbies, and similar agents of functional representation [Schmitter 2000; Crouch 2008]. By employing the organisational weapons of threats, warnings, and conditional promises, the latter can gain a measure of (highly non-transparent) control over public policy that the multitude of individual citizens can hardly match.

\section{Two families of remedies}

Lipset's characterisation of democracy as 'democratic class struggle' emphasises the essential aspect of contestation in the democratic process-the struggle for power among competing representative elites. Yet democratic politics does not just consist in the drama of competition, contestation, and open political conflict (a drama that is eventually to be decided at bargaining tables and by the casting

\footnotetext{
${ }^{1}$ In addition to my triplet of voting/joining/donating as modes of democratic participation (see further below), one might think of 'knowing' (i.e. having access to a reasonably correct picture of the collectively relevant situation and to methods that ensure the truth of the picture). But a discussion of the conditions of adequate- and unbiased-'cognitive participation' would have to focus on the media and their political function, a discussion I have to skip here for reasons of space.
} 
of ballots in elections and the counting of votes). It also consists in the less conspicuous and less easily dramatised process in which citizens form judgments, interests, opinions, and preferences about the matters that affect them and the political community as a whole. The distinction between these two stages is important for democratic political theory; it is the same distinction as that between trying to persuade my opponent in a public exchange of information and argument and outnumbering my opponent through mobilizing support for ' $m y^{\prime}$ party or cause more effectively than the other side is able to. Democratic politics proceeds in cycles that involve both of these stages; we get a one-sided and defective picture of the democratic political process if we think of it only in terms of expressing preferences through voting and elections and not also in terms of the formation and revision of those preferences [Goodin 2004]. The two families of democratic innovations proposals focus on each of these two stages, the expression and the formation of the political will of citizens. The conflict of political wills and preferences as it is expressed in the voting booth is thus preceded by a process of will formation, in which not numbers and the logic of aggregation, but well-informed interpretations of reality, arguments, and reasons can play a decisive role-but so can stereotypes, prejudice, resentments, and the unthinking acceptance of strategically designed messages sent to mass constituencies by competing political elites.

The theoretical claim here is twofold. First, people do not have opinions and preferences (contrary to the reifying assumptions underlying much of survey research); instead, opinions and preferences are essentially in flux and constantly being formed, reproduced, validated, tested, abandoned, adapted, revised, upgraded, and reflectively enriched in the light of new information and experience. On most matters and issues, most people do not have an opinion and policy preference at all most of the time- until, that is, they are challenged to form one (for instance, in spontaneous reaction to being asked a question in a survey, with the implicit expectation communicated being that one 'should' or 'normally does' have a view on the matter in question). Second, the process of opinion and preference acquisition is not exclusively an internal and monological one, but always takes place in communication and interactive dialogue with others. Opinions and preferences are thus social constructs, or the joint outcome of 'my' own capacity and willingness to observe, to learn, and to reason, and of the information and social relations, constraints, expectations, and opportunities in which such learning and reasoning is embedded. We might even argue that it is quite irrational to hold beliefs and preferences which are strictly 'individual' ones, i.e. are formed under conditions of ignorance or disregard about what others, be they opposing 'my' views or concurring with them, hold to be true and desirable. For I know my preferences only after I know the preferences of others on whose cooperation I depend (or whose preferences I need to defeat) in order to realise 'our' preferences and interests. The external context of the ongoing internal process in which opinions and preferences are formed can range from coercive, repressive, or manipulative control over the information that is accessible and the preferences that 
are sanctioned as permissible, to, at the other end of a theoretical scale, egalitarian, open, encouraging, and challenging situations in which individuals are free to rationally consider, knowing and pondering the points of view of others (with whom they may end up agreeing or disagreeing), which beliefs and preferences they choose to form and adopt, and why. It is this latter set of qualities which is summarily referred to, in the broad current of democratic theory that has emerged since the early 1990s, as 'deliberative'.

Coming back to the two stages of democratic inputs-the stage of the formation and the stage of the expression of policy preferences-we must note two asymmetries between them. First, before we can express an opinion or preference, it must have passed through some formative stage (whatever its 'deliberative' qualities), whereas there is no 'must' in the opposite direction: a policy preference, once formed, may well be silenced when it comes to will expression, which may be due to the fact that there is no representative actor (political party, governing elite) who can be expected to 'listen to' and to whom it would make subjective sense at all to address one's expression of will. ${ }^{2}$ The other asymmetry is this: At the stage of the expression of political will, the institutional frameworks of the process-political parties, elections, voting procedures-are all precisely defined and formally prescribed and monitored. In contrast, and while constitutional guarantees (freedoms of opinion, the media, assembly, association, etc.) play an indispensable role as providers of possibilities and opportunities (as do civics curricula and other state-organised educational facilities), much of the actual formation of opinions and political preferences is (and must be according to liberal principles) an institutionally largely uncharted space in which powerful yet informal social processes of family life, work life, the experience within local faith-based and secular communities, neighbourhoods, voluntary associations, consumption and lifestyles, media use, etc., play a decisive role in the formation, validation, and change of political views and preferences and thus the 'social realisation' of those constitutionally guaranteed rights.

2 The widely documented finding that (a) electoral participation ('turnout') is low (i.e. abstention is high), (b) further declining in many 'disaffected' liberal democracies, and (c) increasingly distorted in terms of socioeconomic and educational inequalities (which thus translate into inequalities of political representation) has led scholars to recommend the introduction of mandatory voting, thus eliminating citizens' option to abstain and hiding the gap between preferences and their expression [Lijphart 1997]. Yet if voting were to be made mandatory, at least some voters would find themselves coerced to cast their ballot in favour of parties of whose merits and credibility they are not persuaded. This problem could be remedied by introducing the following rule: If $n$ parties or candidates compete, the voter is given $n+1$ choices (boxes to mark on the ballot), the additional one standing for the option of NOTA ('none of the above'). The perception of political elites' deficient responsivity, as suggested by the evidence of fiscal and institutional conditions constraining state capacity, can in turn contribute to a depoliticising sense of political alienation and powerlessness, which discourages the efforts to acquire political opinions and preferences in the first place. 
The difference between the stages of the formation and the expression of political views and preferences consists in the gap concerning their degree of legal institutionalisation. Statutory (and partly also constitutional) laws exist in all liberal democracies specifying the equal right to vote (i.e. express preferences) of all citizens, the right to stand in elections as a candidate, and the procedures according to which individual votes are aggregated in order to form operating representative institutions. These equal rights are, however, being made actual use of according to highly unequal patterns, namely according to inequalities of socioeconomic and educational status, among others. In contrast, not even such nominal equality is institutionally provided for when it comes to the formation of preferences-the process in which citizens find out about the policy options that are available, each other's arguments and preferences, the composition of potential alliances, and what, in the light of such information, may be deemed as good (or better) for 'all of us', and the remaining disagreements pertaining to this question. Again, prevailing patterns of social inequality seem to condition the highly unequal access to such opportunities of deliberative learning and clarification, with those cut off from relevant communicative and associational resources being not even able to indicate, with any measure of inter-temporal or substantive consistency, where they stand. Others in secure and privileged socioeconomic positions have no doubt concerning this issue, as they are less affected by cognitive uncertainties and motivational cross pressures. It would not be implausible to assume that members of the former category, being confined to a condition of structural uncertainty concerning their own interests and preferences [Lukes 2005], are likely to abstain from participating in political life; only those who know what to say will raise their voices.

These are empirical questions that I cannot pursue here any further. What should have become clear in our discussion of the two stages of political will formation is that liberal democracies suffer from a condition of vast under-utilisation, both quantitative and qualitative, of the political resources that are nominally available to each citizen. By quantitative under-utilisation, I refer to the fact of increasing overall non-participation, increasingly patterned in line with social inequalities. By qualitative under-utilisation, I refer to the malfunctioning of the mechanisms (the media, the educational system, political mass parties) which supposedly can transform 'raw' and unreflective political views and impulses into 'refined' and more enlightened awareness and preferences. Current debates on democratic innovations focus upon either of them and try to devise appropriate remedies. After very briefly pointing to some proposals related to how participation and citizens' involvement can be enhanced in quantitative terms and at the stage of preference expression, the final part of the essay will address some aspects of the hotly debated issue of how the quality of democratic participation might be improved through adopting deliberative procedures and institutions to upgrade the process of preference formation. 
(a) Strengthening the voice of citizens and the expression of their will: modes of aggregation of 'given' individual preferences

Apart from the basic prerequisite of knowing about political issues, alternatives, and institutions, individual citizens can actively participate in politics through three main channels: voting (in general elections), joining (associations, parties, or movements; participating in political discussion), donating (money, time, expertise). All three are affected in contemporary democracies by either a manifest decline of their usage or/and an increasing class bias. That is to say, the middle class and those above it vote, join, and donate more often and more extensively than those below it in terms of income, wealth, socioeconomic security, and education. In order to overcome those biases, a variety of measures have been proposed to facilitate, incentivise, and equalise the expression of political preferences. These include changing the electoral system to a single transferable vote (STV); making voting mandatory (as in Australia, Belgium; Lijphart [1997]); allowing for direct democratic and plebiscitary legislation (with the practices of Switzerland and California serving as a model); enhancing devolution and increasing the autonomy of local governments; democratising the funding of interest associations [Schmitter 2000]; allowing for vicarious voting of parents (one extra vote for every mother per son and every father per daughter; Hinrichs [2002]); introducing gender (and perhaps other, for instance birth-cohort) quotas in the operation of parties, parliaments, and governments [Phillips 1995]; making the number of representatives contingent upon the turnout of constituencies (cf. participatory budgeting in Brazil; Santos [1998]); opening the option for voicing dissent by introducing the NOTA option into the electoral process; making membership fees (more strongly) tax deductible; and reforming political and campaign finance according to the three principles of capping overall expenditures, making 'plutocratic' donations either more anonymous to recipients or transparent to voters (and thus supposedly self-limiting), and financing campaign and political party expenditures out of public revenues [cf. Nassmacher 2009; cf. Ackerman and Ayres 2004]. (For overviews of these and similar proposals for innovation, see Fung and Wright [2003]; Schmitter and Trechsel [2004]; Smith [2005, 2009].)

\section{(b) Improving will formation through deliberation}

There are two premises, or philosophical starting points, of any theory of deliberative democracy: First, the pursuit of any preference that is consistent with the law is legitimate under liberal principles. These principles deny the holders of state power the right (as it was claimed by the holders of power under state socialism) to denounce citizens holding certain (critical) preferences as suffering from 'false consciousness', thus providing a pretext to repress allegedly hostile intentions deriving from it. At the same time, we also need to keep in mind that preferences are not given and 'natural', but formed and motivated through cogni- 
tive and moral considerations, which in turn can be hampered by interests and passions, as well as by communicative conditions that hinder the reflective probing of one's preferences [Offe 1992]. The institutional facilitation of such probing could contribute to the partial or full neutralisation of what Steven Lukes [2005] has called the 'third' - and least conspicuous-face of social power, namely the power to hinder others to find out what their interests are. Moreover, the prevalence of myth, resentment, ignorance, short-termism, the fetishisation of personality and community, and aggressive impulses against elites or minorities can, if they become driving forces behind the perception of political realities and preference formation, seriously jeopardise the viability of liberal democracy. In this sense, political views, values, and preferences are not strictly a 'private' affair of individual citizens, as their pursuit can generate negative externalities that affect the rights of others and ultimately those of 'all of us'. To the extent this is so, we may well claim a public interest in enhancing the overall quality of preferences, mediated through an improvement of the social contexts of preference formation as they demonstrably contribute to such enhancement.

A second premise is this: To repeat, the formation of political (as well as other) preferences is not just a matter of intra-personal, information-gathering, consideration and reflection alone, as in the monological process of 'preference laundering' [Goodin 1982] taking place in some forum internum. Rather (and as argued above), it is a social process in which people find out, preferably in the course of a non-strategic exchange of information and practical reasoning, what other people consider true and desirable and fair for 'all of us' - a process in the course of which the preferences with which people have entered the exchange may undergo revisions. (Whether or not such revisions will verge on consensus is bound to remain an open question for empirical observation.) The rule governing such deliberative exchange is something like this: You know what you want only after you know what others want, and after knowing and considering the reasons on which those others base their preferences. In practical terms, learning about other people's preferences and their reasons for holding them can encourage the formation and clarification of one's own preference on the matter under joint deliberation, provided the exchange takes place with a minimum level of respect and mutual assurance.

The institutional location in which preference formation as a social process takes place is the 'life world' of everyday interaction or, more specifically, the 'third sector' [Goodin 2003] as a residual sphere that is constrained yet not governed by the media of money and formal authority. The sociological distinctiveness of this 'sector' consists in the fact that its organisational forms (foundations, movements, local initiatives and associations, faith-based organisations, etc.) are at the same time non-governmental organisations (NGOs) and non-profit organisations (NPOs). That is to say, what they do is not predominantly guided by criteria of legal correctness (as in public administration) or the ambition to gain law-making powers (as in political parties); and neither is it primarily guided 
by an economic calculus of profitability. Instead, the activities of NGOs/NPOs are dominated by normative intentions and the values to which such intentions relate. Yet, while acting outside of the realms of market competition, political contestation, or hierarchies of authority, such organisations can have a direct impact upon both economic and political processes [Goodin and Dryzek 2006]. The question of by which methods such an impact can be institutionalised in democratic polities [Offe 1997] has led to numerous experiments, institutional innovations, and the empirical observation of the nature of deliberative preference formation and change [Smith 2009; Warren and Pearse 2008].

Since the early 1990s, the philosopher James Fishkin [1991, 1995, 2009] has experimented in many countries and settings with the method of 'deliberative polling'. This method is designed to generate evidence of the 'hypothetical', or counter-factual, will of the people, as opposed to empirical preferences of individuals as they are mirrored by conventional methods of survey research. It shows what people would end up believing and wanting had they had the opportunity to think about, with others and under conditions promoting 'enlightened understanding' [Dahl 2000] and mutual respect, what they 'really' want. The hypothesis, confirmed in many cases, is that the experience of informed deliberation enables participants to clarify, revise, and upgrade their own preferences.In order to demonstrate the amount and the direction of preference revisions, Fishkin's method measures the distribution of opinions and political preferences before and after a relatively short period of deliberation in which a randomly selected group of citizens is invited to participate. When institutionalised-for instance, in the form of 'national issues conferences' preceding national elections or even in the form of an annual 'deliberation day' [Ackerman and Fishkin 2004], this would arguably have a major impact upon political elites: for as a result of deliberative polls, elites are provided with the opportunity to know what the well-considered, as opposed to the 'raw' and unreflected, 'will of the people' is.

\section{The effects of deliberation}

We can distinguish four qualitative effects that the use of deliberative procedures can have upon political life. First, the experience of deliberation can have desirable consequences at the individual level of participants [Fishkin 2009: 133 sequ.; Mutz 2008: 530]. These include, among others, better information on the issue at hand, including the improved awareness of oppositional arguments; an increase in political tolerance and the willingness to compromise, as well as an increase in generalised social trust; an increase in the willingness to participate through voting and civic engagement, and as a result, a greater sense of political efficacy; greater consistency of opinions.

A second effect can consist in the exercise of an informal authority (or a kind of 'soft power') that originates from deliberative procedures once they are institutionalised as part of the political process. As (and to the extent that) the 
media will report on the consensual results and remaining disagreements of deliberating fora and mini-publics, outside observers, elite as well as non-elite, will be provided with the opportunity to learn from the difference (if any) between the 'before' and 'after' poll results in which direction and to what extent the post-deliberation ('refined') preferences will change relative to the 'raw' pre-deliberation ones. The authority of people having passed through deliberation derives precisely (and somewhat paradoxically) from the fact that the participants of deliberative fora are randomly selected ordinary citizens who, representing only themselves rather than parties or interest groups, have neither the intention nor the organisational means to acquire political power themselves. It is the very absence of power ambitions on the part of the deliberators that can increase their 'recommending force' [Fishkin 1995: 162, 2009: 134]. The effect of spreading knowledge about the policy preferences of deliberating (rather than powerseeking) ephemeral bodies will predictably make life more complex for political elites, who, after such polls and the due publication of their outcomes in the media, are then publicly known to know that the so-called 'will of the people' (as registered by ordinary opinion surveys to which they like to refer for legitimation purposes whenever it suits them) may in fact be a mere artefact of the prevailing non-deliberative conditions of preference formation. The public can thus learn that this 'will of the people' is highly malleable and contingent upon contexts of communication. This learning is driven by a demonstration effect: if people actually had the time, expertise, and appropriate communicative framework to think seriously and competently about issues on the political agenda, chances are that they would change their original views and preferences.

Third, there are strong indications that deliberative institutions have not just the potential for widening the range of substantive policy options by bringing to evidence what people want once they have been put in the possession of pertinent information and after having debated arguments for and against the alternative policy options. They also have the potential to widen the social inclusion of participants (and contrary to so much of the anti-intellectual polemics against the idea of deliberation being an idiosyncratic leisure time activity of the educated middle class that is en vogue among conservative academics). Such potential for greater social inclusiveness can be assumed on two grounds. First, to the extent that the principle of random selection of participants can be implemented and self-selection reduced, participants will include categories of people who normally do not vote, join, donate, or even know much about political issues. ${ }^{3}$ But, second-and in a perspective on such forms of non-participation that was first and classically stated by Schattschneider [1960; cf. Offe 2006; Solt 2008]—-there are theoretical arguments and empirical findings suggesting that non-participa-

${ }^{3}$ The random composition of deliberative fora would also increase the diversity of the points of view brought forward, which in itself can add to the informal authority claimed in the previous paragraph. The more diverse the members of a group are, the more immune the results of deliberation are to the suspicion of being biased by special interests. 
tion and the associated waste of political resources is 'endogenous to the failures of democracy' and of 'normal politics' [Neblo et al. 2010: 566, 568] rather than being caused by individual characteristics such as a person's class membership or level of education. The implication of this perspective is of course that if different and additional forms of participation were available, non-participation might well be reduced. Neblo and his co-authors produce strong evidence that deliberation is in fact such an additional, participation-widening procedural device. 'It is precisely people who are less likely to participate in traditional partisan politics who are most interested in deliberative participation.' 'Younger people, racial minorities and lower-income people expressed significantly more willingness to deliberate. ... The kinds of people attracted to the deliberative opportunities offered are fairly distinct from those drawn to partisan politics and interest group liberalism.' [Neblo et al. 2010: 567, 571, 574]

Finally, there are also indications that while the composition of participants in deliberative procedures is designed to approximate randomness, the actual preference change that can be observed in the before/after surveys interestingly does not reflect a random alteration of opinions and attitudes. Instead, deliberative procedures, if conducted under conditions of randomness of participants' characteristics and thus of maximal diversity, generate qualitative outcomes concerning attitude changes and consensual policy recommendations which are not evenly distributed on a conservative-progressive (or 'liberal' in the American sense) dimension of political views and preferences. This finding can be accounted for with a weak and a strong explanatory intuition. The weak one suggests that the very setting of deliberative fora-highly diverse individuals hitherto unknown to each other involved in an exchange of views and arguments on issues of public policy and trying to find solutions preferred by all participants-select against purely self-serving claims and propositions. As the statement ' $\mathrm{I}$ am for policy X because it serves my interest' is unlikely to carry much persuasive power (and perhaps even discredits the speaker because of his or her undisguised selfishness), there is a built-in incentive to present policy preferences, even if they are driven by self-interest, as being adopted for the sake of values or reason-a rhetorical move that can subsequently trap the speaker in a dynamic of self-destructive hypocrisy: once you have started to present your interests as being congruent with common interests or shared values, you have started to force yourself to remain consistent and continue to argue in those terms, which may well lead to actually betraying (in either of the two senses of the word) the interests that were motivating the operation in the first place. Yet there is also reason to consider a strong explanation of how those deliberative procedures may translate into specific, non-random substantive outcomes. As Gastil, Bacci and Dollinger [2010] have shown in an analysis based on attitude changes generated in 65 deliberative polls, there is evidence supporting the presence of a conversion mechanism which translates the procedural equality of the deliberative setting 'into a general orientation toward equal social relations in policy solutions' [Gastil, Bacci and Dollinger 2010: 8]. The authors' main finding is that participants, while not re-de- 
scribing themselves in overall ideological terms of 'liberal' vs 'conservative', still undergo systematic shifts in preferences and beliefs; after participating in (single and relatively short) deliberative fora, participants were 'more likely to support statements that promote cosmopolitanism [and to] oppose those that favor a more nationalist and parochial view of public affairs'. As exposure to the hypothesised causal effect of participating in deliberation was just quite ephemeral, it does not come as a surprise that deliberation was found to 'weakly' promote 'agreement with egalitarian and collectivist worldviews' [ibid.: 20]. Future research must provide us with more robust answers to the question of whether or not we can claim that the institutionalisation of deliberative procedures would shift policy preferences and political views in 'sustainability oriented', 'cosmopolitan', and overall egalitarian and left-liberal directions-directions that are marked by greater fact-regardingness, future-regardingness, and other-regardingness. To the extent that this intuition can be further confirmed through rigorous analysis, the institutionalisation and practical use of deliberative will formation (as a complement to the conventional channels of will expression, namely voting and bargaining) could itself become a promising political project rather than remaining a matter occupying political theorists and empirical researchers.

\section{Structures of deliberation}

Having so far discussed some possible and desirable functions that deliberation can perform, let us, again, move on to the appropriate institutional structures in which these functions might be performed. Deliberative 'mini-publics' [Goodin and Dryzek 2006; Fung and Wright 2003] must ideally conform to three criteria: they must be democratic, both substantively and socially open and unbiased, and consequential. ${ }^{4}$ The first of these criteria, the democratic or rights-egalitarian character, can be fulfilled in two ways. One is 'open access' to an assembly: whoever wants to be present has the right to come and to presents his/her point of view. This applies, for instance, in the case of participatory budgeting or the 'deliberation day' proposal of Ackerman and Fishkin [2004]. The drawback of such self-selection is the presumably significant social selectivity that manifests itself in terms of (i) who shows up and (ii) who takes the floor and speaks and for how long. The answer to both of these questions is likely to be: overwhelmingly members of the educated middle classes plus representatives of parties and interest groups. Moreover, if the assembly is large, deliberation according to the rules of a 'mini-public' is hardly possible. Therefore, and as an alternative to 'open access',

\footnotetext{
${ }_{4}^{4}$ Two additional criteria are discussed by Smith [2009]: procedures must be affordable and transferable to a variety of political issues, i.e. not limited to the most basic issues having to do with electoral systems and the problem of 'choosing how to choose', as in the famous case of electoral reform in the Canadian Province of British Columbia [cf. Warren and Pearse 2008].
} 
advocates of deliberative procedures have typically opted for the random selection of participants and the technique of (stratified) sampling which is intended to make the composition of the mini-public as much as possible a mirror image of the constituency. In this way, an inappropriate role of political party delegates and bearers of functional representation (i.e. interest associations) can be avoided. It must be said, however, that self-selection (and the biases contingent on it, for instance age, education, rhetorical skills) cannot be fully avoided; after all, before a random selection can take place, people must declare their readiness-or else would have to be brought under the equivalent of jury duty or mandatory military service- to actually perform their role in the deliberative body should the lot decide that they are called upon to do so. Yet if the findings of Neblo et al. [2010], referred to above, turn out to be robust, deliberation would provide incentives for self-selection of participants to whom conventional channels of participation and representation do not appeal, thus neutralising the distortions caused by middle class self-selection. Although both of these 'democratic' methods of constituting a deliberative body - open access to assemblies and random selection of participants-clearly have their problems, the variety of experience, opinion, and points of view present in either of them is arguably still greater (and less affected by strategic interests in gaining and maintaining power) than it is in the case in ordinary representative assemblies.

Secondly, deliberative structures should be substantively and socially open and unbiased. Although deliberative settings will hardly ever achieve the criteria of an 'ideal speech situation', there can be a considerable approximation to it through the role of facilitators, or moderators. Participants are asked and constantly reminded by the facilitator to speak out, to listen to others, to behave respectfully, to discipline their political passions, to declare their personal interests related to the issues under discussion, to learn about the issues and alternatives they are dealing with, to respond to the queries and arguments of others; to try to persuade others of their points of view through spelling out reasons; and to arrive at a policy recommendation which reflects, as far as possible, their shared understanding of what conforms to a notion of the common good. In that communicative process, the three virtues, referred to above, will typically be insisted upon by moderators and mutually appealed to by participants: fact-regardingness, other-regardingness, and future-regardingness. As to fact-regardingness, the typical question is: Do we know enough and do we make consistent and unbiased use of that knowledge, in order to develop an adequately informed recommendation on some policy question? Other-regardingness concerns the readiness to take into account the interests, values, and rights of others and issues of social justice pertaining to the way a proposed policy affects interests in favourable or unfavourable ways. And future-regardingness is the ability to look at and evaluate the long-term consequences of the solutions proposed and to deal with issues of their sustainability. In order for a group of deliberators to live up to these demanding standards (and usually under severe time constraints), the group must be small in order to allow for a full presentation of arguments and opinions of 
its members. Also, and in order to enforce the above rules of deliberation, the facilitator must assume the role of enforcing roughly equal participation and an adequate input of information (which is usually provided by a diverse group of experts who are made available for lectures and questioning).

Perhaps hardest to realise is the third criterion: Deliberations of mini-publics must be (known by participants beforehand to have a reasonably reliable prospect to be) consequential, i.e. are guaranteed to have some measure of political impact. This impact can be entirely informal, but even that presupposes that political elites and members of legislative assemblies take mini-publics seriously, and that the media report on the process and outcome (recommendations) of deliberation. 'Planning cells' [Dienel 1997] and 'citizen juries' [Coote and Lenaghan 1997] are cases where the promised impact was to an extent formalised: sponsoring (local) governments made a formal commitment to provide reasons in public should they choose not to follow the recommendations given by deliberating mini-publics. Again the most far-reaching commitment was one that the government of British Columbia made, namely the commitment to hold a referendum on the Assembly's proposal (however one with strong super-majoritarian conditions, which ultimately caused its failure by a narrow margin). At any rate, if the participants cannot rely on the expectation that what they do and come up with has at least some chance of 'making a difference' in public policy, and that their common efforts are recognised as valuable (according to some proposals, also through the payment of a nominal fee paid to deliberators), their readiness to participate, to spend time on learning and understanding, and to properly deliberate will soon be exhausted.

\section{Conclusion}

I introduced this essay by saying that contemporary liberal democracies are 'not functioning well'. Apart from the question of normative standards concerning the characteristics and criteria of a 'well-functioning' democracy that this proposition suggests, it can also be read as an empirical generalisation: Many-and probably an increasing number and highly diverse sorts of-people converge on the belief, expressed in words and even more often in their patterns of behaviour and (in)action, that the way democracies function and the political outcomes they generate are often frustrating, disappointing, short-sighted, unfair, and thus seriously deficient. Rather than this disappointment leading to widely advocated rejection of liberal democracy and its principles, there is an ongoing and vivid democratic meta-discourse on possible improvements, extensions, and innovations of the democratic mode of organising political rule.

In this discourse, participants have focused on various stages of the overall democratic political process. One focus can be described by the question how ruling elites can be prevented from violating the limitations of their office through 
effective constraints that would make them act in more accountable ways. The proposal to strengthen the political role of courts and fiduciary institutions is sometimes made in response to this concern. Another focus is the institutional method by which the multitude of expressions of individual preferences of citizens is to be aggregated and condensed into a single (and time-limited) collective preference. Answers to this question emerge from debates on the pros and cons of electoral systems and the virtues and vices of direct-democratic popular legislation. These two foci have remained almost entirely outside of the present discussion. Instead, I have concentrated on a third and a fourth issue. The former is the issue of actual political participation: how many people are entitled to make use of their democratic rights, how many do actually do so, how often, and concerning what categories of substantive matters. Here belong all democratic innovations that are intended to encourage more, and more evenly distributed, participation through voting and joining and other forms of expressing preferences and choices. Finally, there is the issue of how the preferences that are to be expressed and aggregated come into being in the first place- the formative phase of beliefs and preferences concerning political life. It is at this stage where deliberative modes of forming and revising preferences can come to play a role.

I have argued that the practice of giving reasons, as well as the practice of listening to, respecting, and possibly adopting reasons that others give in an openended and disciplined face-to-face setting can be institutionalised. To that end, participation in such settings would have to be randomised and thereby changed according to egalitarian principles; time, place, and topics of deliberation organised in formal ways; the mutual recognition of dissenting voices guaranteed; the civility of discourses and the availability of relevant information assured; and the public visibility of outcomes, consensual or otherwise, provided for. Institutional forms in which this happens are not a substitute for, but a complement to all those more familiar procedures of democratic politics which regulate the expression and aggregation of preferences and the accountability of office holders. Individual beliefs and preferences are logically prior to their expression and aggregation. Yet beliefs and preferences, the ultimate 'raw material' of the political process, cannot be treated as individually 'given' but are, as social constructs, in constant flux. Also, they are highly incomplete, as most people simply do not know what to believe or which of the alternative decisions to prefer most of the time. Deliberation is the process in which they find out; if properly conducted, it can also be a process in which the three virtues of taking the facts, the well-being of others, and future developments into consideration will be cultivated.

Claus OfFe was (until his retirement in 2005) a professor of political science at Humboldt University, Berlin, where he held the Chair of Political Sociology and Social Policy, after which he held the Chair of Political Sociology at Berlin's Hertie School of Governance. His fields of research include democratic theory, transition studies, EU integration, and welfare state and labour market studies. 


\section{References}

Ackerman, Bruce and Ian Ayres. 2004. Voting with Dollars: A New Paradigm for Campaign Finance. New Haven, CT: Yale University Press.

Ackerman, Bruce and James S. Fishkin. 2004. Deliberation Day. New Haven, CT: Yale University Press.

Coote, Anna and Jo Lenaghan. 1997. Citizens' Juries: Theory into Practice. London: Institute for Public Policy Research.

Crouch, Colin. 2004. Post-Democracy. Cambridge: Polity.

Crouch, Colin. 2008. 'What Will Follow the Demise of Privatised Keynesianism?' The Political Quarterly 79 (4): 476-487.

Crozier, Michel J., Samuel P. Huntington and Joji Watanuki. 1975. The Crisis of Democracy. New York: NYU Press.

Dahl, Robert A. 2000. On Democracy. New Haven, CT: Yale University Press.

Dalton, Russell J. 2004. Democratic Challenges, Democratic Choices. The Erosion of Political Support in Advanced Industrial Democracies. Oxford: Oxford University Press.

Dienel, Peter C. 1997. Die Planungszelle. Eine Alternative zur Establishment-Demokratie. Opladen: Westdeutscher Verlag.

Fishkin, James S. 1991. Democracy and Deliberation. New Directions for Democratic Reform. New Haven, CT, London: Yale University Press.

Fishkin, James S. 1995. The Voice of the People. Public Opinion and Democracy. New Haven, CT: Yale University Press.

Fishkin, James. 2009. When the People Speak. Deliberative Democracy and Public Consultation. Oxford: Oxford University Press.

Fung, Archon and Erik Olin Wright (eds.). 2003. Deepening Democracy. Institutional Innovations in Empowered Participatory Governance. London: Verso.

Gastil, John, Chiara Bacci and Michael Dollinger. 2010. 'Is Deliberation Neutral? Patterns of Attitude Change during "The Deliberative Polls".' Journal of Public Deliberation 6 (2). Retrieved 1 February 2011 (http://services.bepress.com/cgi/viewcontent.cgi?article= 1128\&context=jpd).

Goodin, Robert E. 1982. Political Theory and Public Policy. Chicago: University of Chicago Press.

Goodin, Robert E. 2003. 'Democratic Accountability: The Distinctiveness of the Third Sector.' Archives Européennes de Sociologie 44 (3): 359-369.

Goodin, Robert E. 2004. 'Input Democracy.' Pp. 79-100 in Power and Democracy, edited by Frederik Engelstad and Oyvind Osterud. Aldershot: Ashgate.

Goodin, Robert E. and John S. Dryzek. 2006. 'Deliberative Impacts: The Macro-Political Uptake of Mini-Publics.' Politics and Society 34 (2): 219-244.

Guéhenno, Jean Marie. 1993. La Fin de la démocratie. Paris: Flammarion.

Heller, Hermann. (1933) 1983. Staatslehre. Tübingen: Mohr 1983.

Hinrichs, Karl. 2002. 'Do the Old Exploit the Young? Is Enfranchising Children a Good Idea?' Archives Européennes Sociologiques 43 (1): 35-58.

Kant, Immanuel. (1795) 2006. 'Toward Perpetual Peace.' Pp. 67-109 in Toward Perpetual Peace and Other Writings on Politics, Peace and History. Rethinking the Western Tradition, edited by Pauline Kleingeld. New Haven, CT, London: Yale University Press.

Lijphart, Arend. 1997. 'Unequal Participation. Democracy's Unresolved Dilemma.' American Political Science Review 91 (1): 1-14.

Lipset, Seymor M. 1981. Political Man. Baltimore: John Hopkins University Press.

Lukes, Steven. 2005. Power. A Radical View. London: Palgrave.

Mill, John S. 1861. Considerations on Representative Government. London: Parker, Son, and Bourn, West Strand. 
Mutz, Diana C. 2008. 'Is Deliberative Democracy a Falsifiable Theory?' Annual Review of Political Science 11: 521-538.

Nassmacher, Karl Heinz. 2009. Political Finance. Baden-Baden: Nomos.

Neblo, Michael A., Kevin M. Esterling, Ryan P. Kennedy, David M. J. Lazer and Anand E. Sokhey. 2010. 'Who Wants to Deliberate-and Why?' American Political Science Review 104 (3): 566-583.

O'Connor, James. 1973. The Fiscal Crisis of the State. New York: Saint Martin's Press.

Offe, Claus. 1992. 'Bindings, Shackles, Brakes: On Self-Limitation Strategies.' Pp. 63-94 in Cultural-Political Interventions in the Unfinished Project of Enlightenment, edited by Axel Honnth, Thomas McCarthy, Claus Offe and Albrecht Wellmer. Cambridge, MA, London: MIT Press.

Offe, Claus. 1997. 'Microaspects of Democratic Theory: What Makes for the Deliberative Competence of Citizens?' Pp. 81-104 in Democracy's Victory and Crisis, edited by Axel Hadenius. Cambridge: Cambridge University Press.

Offe, Claus. 2006. 'Political Disaffection as an Outcome of Institutional Practices? Some Post-Tocquevillean Speculations.' Pp. 23-45 in Political Disaffection in Contemporary Democracies. Social Capital, Institutions and Politics, edited by Mariano Torcal and J. R. Montero. London: Routledge.

Pharr, Susan J. and Robert D. Putnam (eds.). 2000. Disaffected Democracies. What's Troubling the Trilateral Countries? Princeton: Princeton University Press.

Phillips, Anne. 1995. The Politics of Presence: The Political Representation of Gender, Ethnicity and Race. Oxford: Oxford University Press.

Rosanvallon, Pierre. 2008. Counter-democracy: Politics in an Age of Distrust. Cambridge: Cambridge University Press.

Santos, Bonaventura de S. 1998. 'Participatory Budgeting in Porto Alegre: Toward a Redistributive Democracy.' Politics E Society 26 (4): 461-510.

Schattschneider, Elmer Eric. 1960. The Semi-sovereign People. New York: Holt, Rinehart and Winston.

Schmitter, Philippe C. 2000. 'The Prospects of Post-Liberal Democracy.' Pp. 25-40 in Kontingenz und Krise, edited by Karl Hinrichs, Herbert Kitschelt and Helmut Wiesenthal. Frankfurt: Campus.

Schmitter, Philippe C. and Alexander H. Trechsel (eds.). 2004. The Future of Democracy in Europe. Trends, Analysis and Reforms. Strasbourg: Council of Europe.

Sen, Armatya. 1999. Development as Freedom. New York: Knopf.

Smith, Graham. 2005. Beyond the Ballot: 57 Democratic Innovations from around the World. Retrieved 1 February 2011 (http://www.powerinquiry.org/publications/documents/ BeyondtheBallot_000.pdf).

Smith, Graham. 2009. Democratic Innovations: Designing Institutions for Citizen Participation. Cambridge: Cambridge University Press.

Solt, Frederick. 2008. 'Economic Inequality and Democratic Political Engagement.' American Journal of Political Science 52 (1): 48-60.

Tocqueville, Alexis de. $(1835,1840)$ 1988. Democracy in America. New York: Vintage.

Torcal, Mariano and J. R. Montero (eds.). 2006. Political Disaffection in Contemporary Democracies. Social Capital, Institutions and Politics. London: Routledge.

Warren, Mark E. 2003. 'A Second Transformation of Democracy?' Pp. 223-249 in Democracy Transformed?, edited by B. C. Cain, R. J. Dalton and Susan E. Scarrow. Oxford: Oxford University Press.

Warren, Mark E. and Hilary Pearse (eds.). 2008. Designing Deliberative Democracy. Cambridge: Cambridge University Press. 